$40 \%$ of patients had symptoms for more than 12 months before starting treatment. Our previous study of the general public's knowledge of diabetes showed that fewer than one in 20 could name the combination of thirst and polyuria as symptoms, suggesting that poor levels of public health education for symptoms related to diabetes may have been an important cause of late presentation. ${ }^{5}$ Furthermore, earlier treatment might have been started in a third of our patients in whom the diagnosis either was made but not acted on or was overlooked. The results of this audit emphasise not only the need to raise awareness of diabetes among health professionals but also to increase the knowledge of major symptoms of diabetes by health promotion among the general public.

1 Knuiman MW, Welborn TA, McCann VJ, Stanton KG, Constable IJ. Prevalence of diabetic complications in relationship to risk factors Diabetes 1986;35:1332-9.

2 Hillson RA, Hockaday TDR, Newton DJ, Pim B. Delayed diagnosis of noninsulin dependent diabetes is associated with greater metabolic and clinical abnormality. Diabetic Med 1985;2:383-6.

3 Mincu I. Micro and macroangiopathies and other chronic degenerative complications in newly diagnosed diabetes mellitus. Medicine International 1970;304:1331-4.

4 WHO Expert Committee on Diabetes Mellitus. WHO Tech Rep Ser 1990;646.

5 Jackson DMA, Wills R, Davies J, Meadows K, Singh BM, Wise PH. Public awareness of the symptoms of diabetes mellitus Diabetic Med 1991;8:971-2.

(Accepted 3 fanuary 1992)

\title{
Maternal serum anti-D antibody concentration and assessment of rhesus isoimmunisation
}

\author{
K H Nicolaides, C H Rodeck
}

Harris Birthright Research Centre for Fetal Medicine, King's College School of Medicine and Dentistry, London SE5 8RX K H Nicolaides, director

Department of Obstetrics and Gynaecology, University College and Middlesex School of Medicine, London C H Rodeck, professor

Correspondence to: Dr Nicolaides:

BMF 1992;304:1155-6
The association between maternal serum haemolytic antibody concentration and outcome of pregnancy has been recognised from the 1950s and measurement of maternal anti-D antibody has been the traditional method of managing pregnancies in which red blood cell isoimmunisation has occurred. Fetal blood sampling from an umbilical cord vessel allows direct assessment of the severity of the disease by measurement of the haemoglobin concentration. ${ }^{1}$ The aim of this study was to determine the association between maternal serum anti-D antibody concentration and fetal anaemia.

\section{Patients, methods, and results}

Fetal blood was obtained by fetoscopy ${ }^{2}(n=93)$ or cordocentesis $^{3}(n=144)$ from 237 pregnancies in which rhesus isoimmunisation had occurred at 17-38 weeks' gestation. The study was cross sectional, and the data were derived from fetuses that had not yet received transfusions. The direct Coombs test was positive in

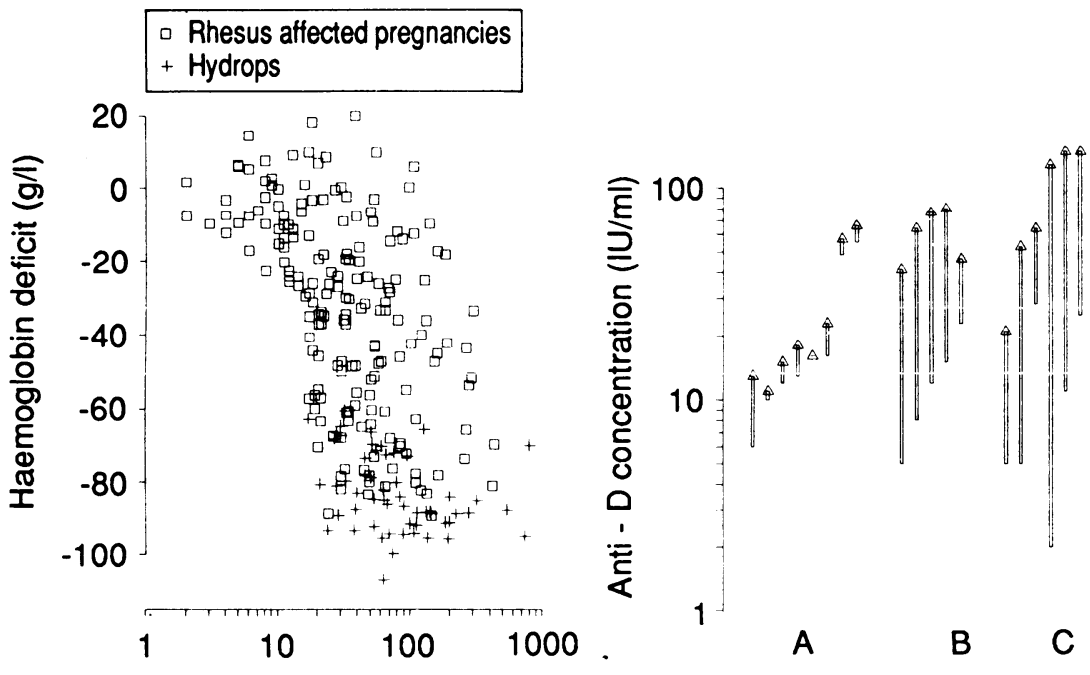

Anti - D concentration (IU/ml)

Left: maternal serum anti-D concentration $(I U / \mathrm{ml})$ and fetal haemoglobin concentration deficit (reduction in haemoglobin $(\mathrm{g} / \mathrm{l})$ from normal mean for gestation) in 237 fetuses from rhesus affected pregnancies. Fifty six hydropic fetuses were severely anaemic (deficit $>60 \mathrm{~g} / \mathrm{l}$ ). When maternal anti-D concentration was $\leqslant 15 \mathrm{IU} / \mathrm{ml}$ fetuses were only mildly anaemic (deficit $<30 \mathrm{~g} / \mathrm{l}$ ). Right: increase in maternal anti-D concentration after first cordocentesis in 19 non-anaemic fetuses; with increase $\leqslant 15 \mathrm{IU} / \mathrm{ml}$ fetuses did not develop significant anaemia $(A)$ whereas with increase $>15 \mathrm{IU} / \mathrm{ml}(B$ and $C)$ six fetuses developed fetal anaemia $(C)$ all fetuses, and Kleihauer staining showed that all samples contained only fetal red cells. The fetal haemoglobin concentration was determined (Coulter S Plus counter, Coulter Electronics, Luton) and the haemoglobin deficit (the amount by which the values differed from the normal mean for gestation) was calculated (normal haemoglobin $=85 \pm 1.4$ gestational weeks, residual $\mathrm{SD}=10 \mathrm{~g} / \mathrm{l}$; this was established from the study of 726 pregnancies with cordocentesis for various indications in which the fetus was retrospectively found to be normal). ${ }^{1}$ The maternal serum anti-D antibody concentration was measured in samples obtained by venepuncture immediately before fetal blood sampling with an autoanalyser calibrated against the British anti-D working standard 72/229 (Technicon Corporation) ${ }^{4}$; the intra-assay coefficient of variation was $10 \%$.

Although $\log _{10}$ maternal anti-D antibody concentration and fetal haemoglobin deficit were significantly associated (figure; $r=0.57, \mathrm{n}=237, \mathrm{p}<0.0001$ ), the wide scatter of results prevents useful clinical application. Nevertheless, in all 42 pregnancies with a maternal anti-D concentration $\leqslant 15 \mathrm{IU} / \mathrm{ml}$ the fetuses were at most mildly anaemic (haemoglobin deficit $<30 \mathrm{~g} / \mathrm{l})$.

In 19 pregnancies in which the fetus was not anaemic further maternal anti-D measurement and cordocentesis were performed two to three weeks subsequently. In the eight pregnancies in which the increase in maternal anti-D antibody was $\leqslant 15 \mathrm{IU} / \mathrm{ml}$ the fetuses remained at most mildly anaemic; in contrast, in six of the 11 pregnancies with an increase in maternal anti-D antibody $>15 \mathrm{IU} / \mathrm{ml}$ the fetus became moderately or severely anaemic (figure).

\section{Comment}

The significant association between the degree of fetal anaemia and maternal serum anti-D antibody concentration is compatible with the pathophysiology of rhesus disease, which involves the extravascular destruction of fetal red cells that are coated with transplacentally derived maternal anti-D antibody. In addition to intra-assay variation, the wide scatter of results may be due to individual variation in rate of transfer of antibody across the placenta, expression of antigens in fetal red cells, and fetal erythropoiesis in response to haemolysis.

In managing rhesus affected pregnancies cordocentesis gives accurate information on the severity of the disease and provides access for fetal intravascular blood transfusion. ${ }^{13}$ Even with experienced operators, however, the risk of fetal death from cordocentesis is about $1 \%$. Furthermore, the procedure is commonly associated with fetomaternal haemorrhage and worsening of the disease. ${ }^{5}$ If the maternal anti-D antibody concentration is $\leqslant 15 \mathrm{IU} / \mathrm{ml}$ the fetus is at most mildly anaemic, and therefore invasive antenatal intervention may not be indicated. In contrast, with a concentration 
of $\geqslant 15 \mathrm{IU} / \mathrm{ml}$ the fetus could be severely anaemic and therefore cordocentesis should be considered.

1 Nicolaides KH, Soothill PW, Clewell WH, Rodeck CH, Mibashan R, Campbell $S$. Fetal haemoglogin measurement in the assessment of red cell isoimmunisa. Fol hase

2 Rodeck CH, Nicolaides KH, Warsof SL, Fysh WJ, Gamsu HR, Kemp JR. The management of severe rhesus isoimmunisation by fetoscopic intravascular transfusions. Am f Obstet Gynecol 1984;150:769-74.
Nicolaides KH, Soothill PW, Rodeck CH, Clewell W. Rh disease: intravascular fetal blood transfusion by cordocentesis. Fetal Therapy 1986;1:185-92.

4 Marsh WL, Nichols M, Jenkins WJ. Automated detection of blood group antibodies. Fournal of Medical and Laboratory Technology 1968;25:335-42.

5 Nicolini U, Kochenour NK, Greco P, Letsky EA, Johnson RD, Contreras M, et al. Consequences of fetomaternal haemorrhage after intrauterine transfusion. $B M \mathcal{F} 1988 ; 297: 1379-81$.

(Accepted 13 fanuary 1992)

\section{Inhaled atrial natriuretic peptide and asthmatic airways}

\author{
Geoffrey Hulks, Neil C Thomson
}

Department of Respiratory

Medicine, Western

Infirmary, Glasgow

G11 6NT

Geoffrey Hulks, Wellcome

Research Fellow

Neil C Thomson, consultant physician

Correspondence to:

Dr G Hulks, Department of Respiratory Medicine, City Hospital, Edinburgh EH10 5SB.

$B M \mathcal{7}$ 1992;304:1156 cyclic AMP.
Pathophysiological plasma concentrations of atrial natriuretic peptide have been shown to have a bronchodilator effect in constricted asthmatic airways, ${ }^{12}$ and lower doses may decrease bronchial hyperresponsiveness, ${ }^{3}$ a hallmark of asthma. This observation is of considerable interest as animal models suggest that the intracellular action of atrial natriuretic peptide in the airway is mediated by cyclic GMP, ${ }_{4}$ whereas $\beta$ agonists, which are the current first line bronchodilator treatment for asthma, act through

Drugs for treating airway diseases are best given directly into the airway itself, and the purpose of this study was to ascertain any bronchoprotective effect of inhaled atrial natriuretic peptide.

\section{Subjects, methods, and results}

We studied eight subjects (three women) with atopic asthma. Their mean forced expiratory volume in one second $\left(\mathrm{FEV}_{1}\right)$ was $94 \%$ (SD $8 \%$ ) of the predicted value. All subjects showed at least moderate bronchial hyperreactivity to inhaled histamine-that is, histamine at a concentration of $\leqslant 2 \mathrm{mg} / \mathrm{ml}$, produced $\geqslant 20 \%$ fall in $\mathrm{FEV}_{1}$.

On three separate days subjects received either nebulised atrial natriuretic peptide $(0.1 \mathrm{mg}$ or $1 \mathrm{mg})$ or placebo in a double blind, randomised manner. FEV was tested at 30,90 , and 180 seconds after inhalation and immediately thereafter a single two minute inhalation of histamine was given in a dose extrapolated from the screening visit to produce a $25 \%$ fall in FEV $\mathrm{FEV}_{1}$ was measured again at 30,90 , and 180 seconds and repeated at $5,10,15$, and 20 minutes.

Forced expiratory volumes at baseline and after atrial natriuretic peptide were compared by analysis of variance.

There was no significant variation in baseline $\mathrm{FEV}_{1}$ between study days nor was there any significant change in $\mathrm{FEV}_{1}$ after atrial natriuretic peptide alone. All subjects showed a pronounced inhibition of histamine induced bronchospasm with $1 \mathrm{mg}$ atrial natriuretic peptide (figure). The maximum fall in $\mathrm{FEV}_{1}$ was 26.8 (SE 0.7 ) $\%$ with placebo, $22.6(3.3) \%$ with $0 \cdot 1 \mathrm{mg}$ atrial natriuretic peptide, and $9 \cdot 2(2 \cdot 2) \%$ with $1 \mathrm{mg}(\mathrm{p}<0.001$, placebo $v 1 \mathrm{mg}$ atrial natriuretic peptide). No side effects were reported or observed.

\section{Comment}

This is the first report that atrial natriuretic peptide effectively protects the hyperreactive airway when given by inhalation. The observation is of particular interest as atrial natriuretic peptide is believed to work by a linkage of guanyl cyclase and the generation of cyclic $\mathrm{GMP}^{4}$ and thus represents a different intracellular mechanism to $\beta$ agonists, for which the

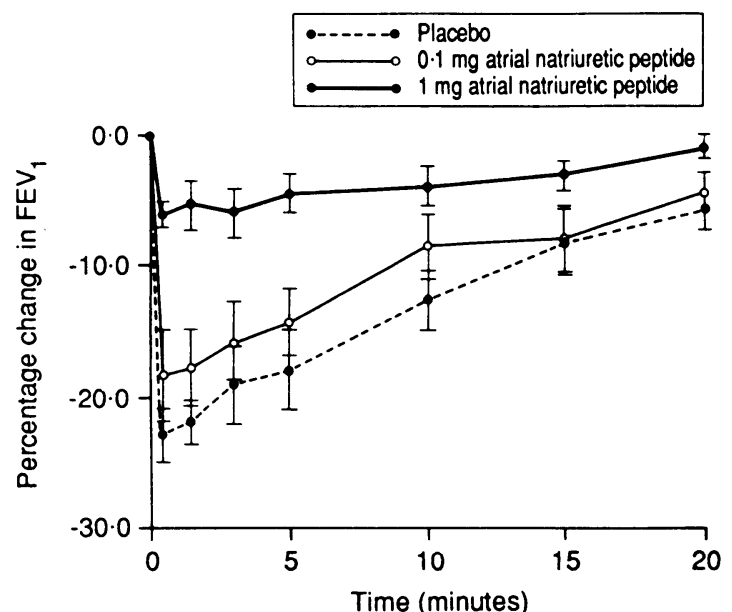

Mean (SE) change in forced expiratory volume in one second in response to inhaled histamine after pretreatment with inhaled atria natriuretic peptide in eight asthmatic subjects

generation of cyclic AMP is linked to adenyl cyclase.

We assume that atrial natriuretic peptide achieves its effect by acting directly on smooth muscle in the airway. In support of this, animal models have shown that atrial natriuretic peptide in tracheal preparations has a direct, dose dependent, relaxant effect. ${ }^{45}$ Atrial natriuretic peptide has been localised by autoradiography to smooth muscle in rat bronchi and bronchioles, but a receptor population in the human airway has not been directly sought. It should be emphasised that other possibilities remain to account for the observed effect. Atrial natriuretic peptide has been shown to exert some of its renal effects by altering mucosal ion transport, and similar effects in airway smooth muscle might affect airway reactivity. Atrial natriuretic peptide can modulate vagal activity and ganglionic neurotransmission and, although this evidence pertains to vascular models, similar actions in the airway could be relevant.

We have shown that a substance believed to act by a different intracellular mechanism to current first line bronchodilator treatment for asthma has a significant bronchoprotective effect when given by inhalation. We therefore suggest that natural or synthetic compounds that work by a similar mechanism warrant further investigation as potential therapeutic agents to be given by this route.

GH was supported by a Wellcome medical graduate fellowship. The cost of atrial natriuretic peptide was met by a grant from the Chest, Heart, and Stroke Association (Scotland)

1 Hulks G, Jardine A, Connell JMC, Thomson NC. Bronchodilator effect of atrial natriuretic peptide in asthma. BMF 1989;299:1081-2.

Chanez P, Mann C, Bousquet J, Chabrier PE, Godard P, Braquet P, et al. Atrial natriuretic factor (ANF) is a potent bronchodilator in asthma. $f$ Allergy $C$ lin Immunol 1990:86:321:4.

3 Hulks G, Jardine A, Connell JMC, Thomson NC. Influence of elevated plasma levels of atrial natriuretic factor on bronchial reactivity in asthma. Am Rev Respir Dis 1991:143:778-82.

4 Ishii K, Murad F. ANP relaxes bovine tracheal smooth muscle and increases cGMP. Am I Physiol 1989;256(Cell Physiol 25):C495-500.

5 O'Donnell M, Garippa R, Welton AF. Relaxant activity of atriopeptins in isolated guinea-pig airway and vascular smooth muscle. Peptides
1985;6:597-601.

(Accepted 20 January 1992 